(C) Sarah Wade, 2020. The definitive, peer reviewed and edited version of this article is published in Journal of Curatorial Studies, 9.2, 2020, 162-181, DOI: 10.1386/jcs_00019_1 and URL:

https: / / www.ingentaconnect.com/ contentone/intellect/jcs / 2020/00000009/00000002 / art00002

SARAH WADE

University of East Anglia

\title{
Ecological Exhibitions at the Musée Océanographique de Monaco
}

\begin{abstract}
In 2010, the Musée Océanographique de Monaco initiated a contemporary art programme to mark its centenary and reaffirm commitment to its founding premise of displaying objects of both art and science. Ever since, the Museum has regularly staged exhibitions promoting marine wildlife protection. I argue that as well as examining ecological concerns, these exhibitions have functioned in ecological ways, adopting curatorial approaches that traverse art and science to highlight interconnections between humans and ocean life. By revisiting historical modes of display such as the Wunderkammer and deploying anthropomorphism, the Museum presents ecologies of display that aim to evoke solidarity with marine wildlife. Yet, ambiguity arises when considering these exhibitions in the context of this institution and its longer history, which I suggest requires an on-going curatorial commitment to finding creative and thoughtful ways of responding to ecological issues in museums.
\end{abstract}

\section{Keywords}

curating and conservation

exhibitions and ecology

Mark Dion 
(C) Sarah Wade, 2020. The definitive, peer reviewed and edited version of this article is published in Journal of Curatorial Studies, 9.2, 2020, 162-181, DOI: 10.1386/jcs_00019_1 and URL:

https: / / www.ingentaconnect.com/ contentone/intellect/jcs / 2020/00000009/00000002 / art00002

Oceanographic Museum of Monaco

Oceanomania

On Sharks E Humanity

Sharks: A Thrilling Experience

Wunderkammer

(figure 1)

Built into a cliff face on the Rock of Monaco and looking out across the sea from which its contents are derived and inspired, the Musée Océanographique de Monaco ('Oceanographic Museum of Monaco') was founded by the dedicated oceanographer Prince Albert I of Monaco (1848-1922). In a monumental building designed by the architect Paul Delefortrie (1843-1910), the Museum was inaugurated in 1910 to house the specimens the prince collected for study and research on 28 oceanographic expeditions, undertaken between 1885-1915 across the North Atlantic and Mediterranean, with the aim of disseminating knowledge about the sea and its inhabitants (Oceanographic Museum of Monaco 2011: 7-8). The institution hosted regular colloquia on scientific and environmental issues and provided aquaria and laboratory space for scientists and researchers for the study of the world's oceans, as it continues to do today. As well as displaying natural history specimens, live animals and the tools of the oceanographer's trade, this institution also realized its founder's vision to gather together what he claimed were 'the two driving forces of civilisation: Art and Science' (Prince Albert I quoted in Calcagno and Beaud 2011a: 3). 
(C) Sarah Wade, 2020. The definitive, peer reviewed and edited version of this article is published in Journal of Curatorial Studies, 9.2, 2020, 162-181, DOI: 10.1386/jcs_00019_1 and URL:

https: / / www.ingentaconnect.com/ contentone/intellect/jcs / 2020/00000009/00000002 / art00002

When the Museum celebrated its centenary in 2010, this milestone anniversary year was commemorated through a series of restoration works and the launch of a contemporary art programme (Bine-Muller 2010). The latter was conceived on the basis of presenting artworks amongst the existing displays, reinforcing the founding prince's vision for this museum to contain objects of both art and science. By this point, the display of artistic interventions in museum collections was an established field of curatorial practice, having gained momentum since the 1990s when curators of non-art museums adopted this tactic to aid interpretation, broaden audiences and also critically reflect on museums and their histories by incorporating artworks to perform institutional critique and decolonize museum spaces. ${ }^{2}$ The contemporary art programme at the Musée Océanographique de Monaco additionally came in the wake of various art-science projects, including long-term contemporary art programmes at a number of national science museums, whereby artworks were used as narrative devices, educational tools and a means to prompt debate (Rossi-Linnemann and Martini 2019: 13). ${ }^{3}$ The Musée Océanographique de Monaco has frequently utilized the display of contemporary art to specifically engage visitors with ecological concerns and advocate for the protection of marine species and habitats, in line with its mission of knowing, loving and protecting the oceans and echoing Prince Albert I's early concerns about the anthropogenic threats facing ocean life (H.S.H. The Prince of Monaco 1921: 181-82). With over 650,000 visitors a year and a comprehensive events programme and website, these exhibitions have provided possibilities for raising awareness about environmental concerns, ranging from ocean pollution to shark finning, to a substantial international audience. 
(C) Sarah Wade, 2020. The definitive, peer reviewed and edited version of this article is published in Journal of Curatorial Studies, 9.2, 2020, 162-181, DOI: 10.1386/jcs_00019_1 and URL:

https: / / www.ingentaconnect.com/ contentone/intellect/jcs / 2020/00000009/00000002 / art00002

The Musée Océanographique de Monaco is far from being the only museum engaged in this type of marine-themed ecological exhibition making. However, it is a notable case study since it is an historical institution conceived on the basis of what today appear to be very contemporary concerns with regards to its artistic-scientific premise. The Museum therefore provides an important precedent for the recent wave of contemporary exhibitions entangling ocean ecology, art and science and begins to chart the heritage of this sea-themed field of curatorial practice. ${ }^{4}$ In addition, the Musée Océanographique de Monaco provides a pertinent context to explore ecological exhibitions as a concept in terms of how they are defined and theorized. While scholars have given much attention to exhibitions concerned with ecological content, there has been more limited work focussing on how exhibitions might be ecological in themselves, in terms of how they function and even their environmental credentials (Cameron 2015; Wehner 2017). Curators have variously developed exhibitions exploring environmental concerns, yet these have less often been used as a platform to consider what forms a 'green' museum in the twenty-first century might take and the practices such an institution might adopt (Rectanus 2020: 126). The Musée Océanographique de Monaco provides a unique case study to explore these more embedded ecological approaches in action.

This article argues that exhibitions at this Museum have worked in ecological ways, adopting curatorial approaches that have entangled nature and culture and collapsed the boundaries between humans and nonhumans to foster an ecological sensibility towards marine wildlife in visitors. It focuses specifically on the American artist Mark Dion's installation Oceanomania: (2011-12) and the shark conservation 
(C) Sarah Wade, 2020. The definitive, peer reviewed and edited version of this article is published in Journal of Curatorial Studies, 9.2, 2020, 162-181, DOI: 10.1386/jcs_00019_1 and URL:

https: / / www.ingentaconnect.com/ contentone/intellect/jcs / 2020/00000009/00000002 / art00002

exhibition programme that ran at the museum from 2013 to 2015, which aimed to raise awareness about the threats facing ocean life. Oceanomania appropriated an historical mode of display in the form of the Wunderkammer, which, as a curatorial device experiencing a revival in recent years, I suggest offers contemporary museums opportunities to foster new ways of thinking through their historical collections and the current ecological crisis. As a mode of display it can also harness the affective potential of wonder to induce a desire to care. The shark exhibitions, on the other hand, utilized anthropomorphism to render these sea creatures familiar, rather than feared. While anthropomorphism is often criticized in scientific research, I demonstrate how it can play a crucial role in museums to aid understanding and evoke empathetic responses in visitors. These curatorial strategies provided effective ways of engaging visitors with environmental issues at this museum, yet certain ambiguities arose when considering these exhibitions in the context of the institution and its longer history. The environmental philosopher Timothy Morton makes clear that being ecological is often marked by ambiguity (2018: 108) and as such, this article concludes by proposing a curatorial approach for grappling with contradictions and inconsistencies when developing ecological exhibitions in museums.

\section{Ecologies of Display}

The Musée Océanographique de Monaco is a particularly relevant museum in which to explore ecological exhibitions, not only because of its environmental agenda, but also as a result of its founding premise to display objects of both art and science. The museum studies scholar Fiona Cameron has argued that if contemporary museums are to engage 
(C) Sarah Wade, 2020. The definitive, peer reviewed and edited version of this article is published in Journal of Curatorial Studies, 9.2, 2020, 162-181, DOI: 10.1386/jcs_00019_1 and URL:

https: / / www.ingentaconnect.com/ contentone/intellect/jcs / 2020/00000009/00000002 / art00002

with environmental issues in meaningful ways, they must first dispense with the modern dualisms that informed their very founding in the nineteenth century and that frequently pervade displays today. The reason being that such dualistic tendencies do not recognize the ways humans and nonhumans are entangled in the world (2015: 1618). Delineating and reinforcing binaries such as nature/culture and human/nonhuman has the effect of separating humanity from the 'mesh' of earthly life in a way that can forestall a sense of ecological solidarity with others in the face of environmental distress (Morton 2010: 15). The Musée Océanographique de Monaco has resisted binary approaches to collecting and displaying knowledge from the very outset, making it a productive context in which to engage with environmental issues on the terms that Cameron sets out.

At the same time that other museums were separating artistic and scientific disciplines into the different institutions emerging to house them, the Musée Océanographique de Monaco was inaugurated on the basis of bringing art and science together. ${ }^{5}$ Accordingly, as well as displaying live species in aquaria, natural history specimens and oceanographic instruments the Museum also presented numerous paintings, housed an extensive collection of works on paper - many of which were produced aboard the prince's expeditions - and decoratively incorporated various sea life into the interior design and architecture of the museum building itself.

The design concept paid homage to Art Nouveau style as much as to the creatures of the deep. Throughout the Museum's grand interiors, decorative floor mosaics depict cephalopods, fish, crustaceans and siphonophores. An elaborate glass chandelier hanging in the Museum's Salon d'Honneur designed by the French sculptor 
(C) Sarah Wade, 2020. The definitive, peer reviewed and edited version of this article is published in Journal of Curatorial Studies, 9.2, 2020, 162-181, DOI: 10.1386/jcs_00019_1 and URL:

https: / / www.ingentaconnect.com/ contentone/intellect/jcs / 2020/00000009/00000002 / art00002

Constant Roux (1865-1942) was based on the biologist Ernst Haeckel's illustration of the jellyfish Rhopilema frida. Ceiling panels in the ostentatious conference room feature paintings of shells, sea birds and scenes of whaling, while stained glass windows show mermaids (Bine-Muller 2010: 38-41, 48-57). The decorative stonework on the building's exterior bears the names of vessels that carried out significant scientific expeditions during the nineteenth century as well as various sculptural marine life, including an albatross, osprey and walrus by the sculptor Gustave Dussart (1875-1952). ${ }^{6}$

Nature and culture were similarly entwined through the Museum's displays, which in the institution's early years were arranged across three rooms dedicated to zoology, physical oceanography and applied oceanography (Oceanographic Museum of Monaco 2011: 9-10). The zoology displays featured articulated skeletons, taxidermy and other preserved specimens of deep-sea fauna, collected by the prince during his scientific expeditions and displayed according to their oceanic order. ${ }^{7}$ These included the remains of cetaceans that the prince harpooned himself to inform his studies (Oceanographical Museum and Aquarium 1935: 7). The physical oceanography room comprised various scientific instruments and the applied oceanography room focused on the role of the sea in everyday life and culture, presenting ornaments and jewellery fabricated from sea-derived materials like coral and shell, decorative arts and ceramics inspired by the ocean, and objects used at sea such as fishing nets and baskets. The first floor of the museum contained models of the prince's sailing vessels, as well as a model of a whaling boat and a life-size recreation of the laboratory aboard the prince's yacht Hirondelle II (Oceanographical Museum and Aquarium 1935: 8). Today, the collection displays are installed on the first floor of the Museum and split across the Whale Room, 
(C) Sarah Wade, 2020. The definitive, peer reviewed and edited version of this article is published in Journal of Curatorial Studies, 9.2, 2020, 162-181, DOI: 10.1386/jcs_00019_1 and URL:

https: / / www.ingentaconnect.com/ contentone/intellect/jcs / 2020/00000009/00000002 / art00002

which contains natural history specimens including cetacean skeletons dramatically hanging from the ceiling, and a recently redesigned multimedia display entitled Monaco and the Ocean, which opened in July 2018 and focuses on the history of human relationships with the ocean through the lifetimes of three of Monaco's princes.

Many of the temporary exhibitions staged at this museum since its centenary year have similarly resisted disciplinary specificity, being curated in such a way that displays transgressed the confines of the arts and the sciences and brought them into relation with one another to address ecological concerns. At this institution, curatorial tactics have facilitated dialogues between the historical collection and contemporary artworks, human and nonhuman artefacts, preserved specimens and living species, which co-habit the museum space in ecological ways, diluting the boundaries between nature and culture at this Museum. This mode of exhibition making is ripe for performing what Cameron calls 'ecologizing experimentations', a new materialist approach to curating museum collections premised on acknowledging the entanglements of humans and nonhumans and exploring the possibilities for reconfiguring the relationships between associated museum objects to result in new narratives (2015: 23). The outcome is a curatorial approach that on Cameron's terms can produce displays more attuned to today's ecologically troubled times by presenting humans and nonhumans as inextricably entwined, thus reflecting the reality of life of Earth (2015: 23-24). At the Musée Océanographique de Monaco this provides a strategic way forward for developing exhibitions to engage visitors with environmental concerns. 
(C) Sarah Wade, 2020. The definitive, peer reviewed and edited version of this article is published in Journal of Curatorial Studies, 9.2, 2020, 162-181, DOI: 10.1386/jcs_00019_1 and URL:

https: / / www.ingentaconnect.com/ contentone/intellect/jcs / 2020/00000009/00000002 / art00002

By adopting this ecological approach, exhibitions at this museum have the capacity to evoke a sense of kinship with marine wildlife, which can subsequently induce a desire to care. For Timothy Morton, being ecological means that everything is interconnected and requires 'coexisting nonviolently with nonhuman beings' (2018: 108). Morton suggests that ecological art - or in this context, ecological exhibitions - is that which 'brings this solidarity with the nonhuman to the foreground' (2018: 121). Recent exhibitions at the Musée Océanographique de Monaco, including Oceanomania, Sharks: A Thrilling Experience (2013-15) and On Sharks E Humanity (2014-15) have adhered to these ecological criteria, promoting and advocating for the protection of species and habitats, thereby foregrounding solidarity with marine wildlife on Morton's terms at the same time as functioning in ecological ways.

\section{Oceanomania: An Ecological Wunderkammer}

In 2011, Mark Dion assumed the role of the artist-curator and presented Oceanomania: Souvenirs of Mysterious Seas, From the Expedition to the Aquarium, a large multi-site exhibition in Monaco. ${ }^{8}$ As part of the project, Dion was commissioned to create a new site-specific work at the Musée Océanographique de Monaco. The resulting installation took the form of a giant cabinet of marine curiosities, or Wunderkammer, containing objects, specimens and nonhuman animal remains that Dion selected from the museum's collections and stores in collaboration with staff. Covering a display area of some 200 square metres, the huge installation, which was also entitled Oceanomania, was subsequently retained as a permanent feature at the museum and is still on display today (Calcagno and Beaud 2011b: 19). 
(C) Sarah Wade, 2020. The definitive, peer reviewed and edited version of this article is published in Journal of Curatorial Studies, 9.2, 2020, 162-181, DOI: 10.1386/jcs_00019_1 and URL:

https: / / www.ingentaconnect.com/ contentone/intellect/jcs / 2020/00000009/00000002 / art00002

(Figure 2)

Like its early modern counterpart, Dion's contemporary cabinet of curiosities contains an abundant selection of artificialia, naturalia and scientifica. The varied objects on display include natural history specimens in the form of taxidermy, wet specimens and models, scientific publications such as the bulletins published by the

Oceanographic Institute, ${ }^{9}$ models of ships, objects worked by hand - including coral formed into jewellery and scrimshaw, an antique diving suit, a 'mermaid' (actually a fish tail fused to a monkey body), ${ }^{10}$ large quantities of shells, fishing nets, harpoons, paintings, scientific instruments and a comprehensive selection of books by the renowned ocean explorer and filmmaker Jacques-Yves Cousteau, who served as the Museum's director for over 30 years. As a result of the varied content, Oceanomania testifies to the various relationships humans have developed with the sea and ocean inhabitants throughout history, be these of use, abuse, intrigue, scientific study, as a source of artistic inspiration or as a resource for exploitation. Considering such paradoxes, it is notable that Oceanomania was produced in the wake of two converging marine events - the 2010 Deepwater Horizon oil rig disaster, which had disastrous and deleterious effects on wildlife after an estimated 4.9 million barrels of crude oil spilled into the sea of the Gulf of Mexico, and the 2010 Census of Marine Life, whereby scientists from 80 nations came together to explore the biodiversity of the world's oceans, discovering some 6,000 new species in the process. ${ }^{11}$ Given this ecological context, the fact that Dion adopted the cabinet of curiosities for his work is significant 
(C) Sarah Wade, 2020. The definitive, peer reviewed and edited version of this article is published in Journal of Curatorial Studies, 9.2, 2020, 162-181, DOI: 10.1386/jcs_00019_1 and URL:

https: / / www.ingentaconnect.com/ contentone/intellect/jcs / 2020/00000009/00000002 / art00002

and the curatorial decision to commission this installation was a strategic move, which facilitated the mobilization of the Museum's historical collections to address the ecological issues of today (Jeffery 2015a: 176).

As has been well documented, early modern cabinets of curiosities housed abundant collections amassed by princes, merchants and apothecaries for study and the display of wealth, knowledge and power. ${ }^{12}$ The objects they contained were often rare and extraordinary, eliding classification so that art and nature became blurred and even entwined, having the effect of evoking 'intense wonder' in viewers (Daston and Park 2001: 260). Crucially, an encounter with such a cabinet was an interactive and multisensory experience. Displays were arranged in a way that invited viewers to explore the contents and formulate relationships between the disparate objects, demanding active sensory and intellectual engagement (Stafford 2001: 14, 20).

Since the mid-1980s, the early modern cabinet of curiosities has received much scholarly attention..$^{13}$ Over the last 20 years it has also proliferated as a mode of display and an object of critique in numerous artworks and exhibitions, garnering critical attention in the process. ${ }^{14}$ These range from the artist Rosamund Purcell's recreation of the early modern natural philosopher Olaus Worm's cabinet in All Things Strange and Beautiful (2003) to Mark Dion's more recent insertion of new curiosities into Dresden's Green Vaults as part of The Academy of Things (2014-15) (Lange-Berndt and Rübel 2015). Notably, the cabinet of curiosities has also been visually evoked through the recent installation of several mass displays at various natural history museums. These include the Spectrum of Life in the Hall of Biodiversity at the American Museum of Natural History in New York (1998), the Wall of Biodiversity at the Museum für Naturkunde in 
(C) Sarah Wade, 2020. The definitive, peer reviewed and edited version of this article is published in Journal of Curatorial Studies, 9.2, 2020, 162-181, DOI: 10.1386/jcs_00019_1 and URL:

https: / / www.ingentaconnect.com/ contentone/intellect/jcs / 2020/00000009/00000002 / art00002

Berlin (2007) and the Wunderkammer at Venice's Museo di Storia Naturale (2011), testifying to a revival of the aesthetic of this pre-Enlightenment mode of display in the context of natural history collections, as well as in contemporary art.

Yet, as a contemporary mode of display, the cabinet of curiosities presents a paradox that needs to be considered. It is notable that the trend for visually referencing the cabinet of curiosities to present wildlife in museums coincides with the hastening disappearance of species from the wild. These mass displays of biodiversity provide one possible response to the crisis of the Sixth Mass Extinction, representing an attempt to preserve a record of plentiful nonhuman animal life as it disappears from the wild at an increasingly accelerating rate. ${ }^{15}$ As exhibits, they embody a certain ambiguity, manifesting the feminist philosopher Donna Haraway's oft-quoted observation that 'Once domination is complete, conservation is urgent' through the tragic irony of hundreds of animal remains being put on display at a time marked by extinction (1984: 28). Indeed, the novelist, thalassophile and whale expert Philip Hoare (2014) suggested that the prevalence of the cabinet of curiosities as a display trope in museums and galleries today 'speaks to our own vexed relationship with the natural world, at a time when we seem bent on destroying it'. So while the resurgence of interest in the Wunderkammer as a mode of display is clearly visible in recent artistic and curatorial practice, the reasons it has resurfaced and its relationship to the early modern counterpart need to be more thoroughly unpacked. Not least because these early modern cabinets of curiosities often contained the spoils of colonial conquest resulting from the so-called 'Age of Discovery', making them not unproblematic models of display given the violence they represent and the deaths, and even extinctions, with 
(C) Sarah Wade, 2020. The definitive, peer reviewed and edited version of this article is published in Journal of Curatorial Studies, 9.2, 2020, 162-181, DOI: 10.1386/jcs_00019_1 and URL:

https: / / www.ingentaconnect.com/ contentone/intellect/jcs / 2020/00000009/00000002 / art00002

which they are embroiled.

Adopting the cabinet of curiosities as a mode of display might therefore initially seem at odds with any ecological intent. However, it offers strategic possibilities as a curatorial device that can harness the ethical potential of wonder and perform the sort of 'ecologizing experimentations' that Cameron claimed can result in exhibitions more attuned to the current environmental state of play. It is notable that Cameron suggested that urgent action in the face of ecological distress involves not just innovation, but that 'we engage afresh with familiar established concepts and constructions' (2015: 16). The cabinet of curiosities provides a promising model for this type of revisionary activity. The curious interconnections and unexpected relationships forged via encounters with a Wunderkammer offer critical possibilities today. As a curatorial device, it provides the opportunity to bridge temporalities, geographies and topics to foster novel, transdisciplinary ways of thinking through the current ecological crisis (Robin 2018: 217). ${ }^{16}$ The environmental humanities scholar Stacy Alaimo claimed that the Anthropocene, as a new geological epoch proposed to recognize the damaging human impact on Earth, is not a 'time for transcendent, definitive mappings, transparent knowledge systems, or confident epistemologies', since, 'Surely all those things got us into this predicament to begin with', fostering a mind-set of domination and subjugation (2016: 3). ${ }^{17}$ As a contemporary display strategy, the cabinet of curiosities allows for more uncertain modes for the creation and display of knowledge, which might unmoor viewers from traditional disciplinary frameworks and free them from the authoritative expectations of the museum experience. In turn, this provides scope for encouraging new and unexpected ways of thinking through familiar topics via an 
(C) Sarah Wade, 2020. The definitive, peer reviewed and edited version of this article is published in Journal of Curatorial Studies, 9.2, 2020, 162-181, DOI: 10.1386/jcs_00019_1 and URL:

https: / / www.ingentaconnect.com/ contentone/intellect/jcs / 2020/00000009/00000002 / art00002

exhibitionary format. At the same time, the interconnections made possible through encounters with a Wunderkammer have the capacity to reinforce the entanglements between humans and nonhumans that are so integral to both ecological thought and action.

By referencing the early modern cabinet of curiosities, Oceanomania entwines nature and culture, humans and nonhuman animals, and past, present and future encouraging viewers to freely and fluidly reflect on the various relationships humans have developed with the sea and marine wildlife throughout history (Jeffery 2015a: 176, 182). In this way, the work performs an 'ecologizing experimentation', providing space to think through and reconfigure relationships between humans and nonhumans in a display about the oceans at a time of ecological crisis. Given that Cameron claims ecologizing experimentations can create 'a new position from which interspecies transactions can be made' in order to 'promote [...] an ethics of care beyond the human world' (2015: 29, original emphasis), the cabinet of curiosities is a productive curatorial tool in the context of this museum considering its mission to promote knowing, loving and protecting the oceans. By drawing attention to the intrinsic ecological reality that everything is interconnected (Morton 2010: 15), Oceanomania reinforces the interrelationships between humans and ocean life, creating circumstances more conducive to fostering solidarity with nonhuman others in the context of this Museum.

Wonder also has a role to play here. Early modern cabinets of curiosities evoked wonder through the blurring of the boundaries between art and nature, the presentation of the rare and extraordinary, and the sheer abundance of all that was on display (Daston and Park 2001; Kenseth 1991). As the science historians Lorraine Daston 
(C) Sarah Wade, 2020. The definitive, peer reviewed and edited version of this article is published in Journal of Curatorial Studies, 9.2, 2020, 162-181, DOI: 10.1386/jcs_00019_1 and URL:

https: / / www.ingentaconnect.com/ contentone/intellect/jcs / 2020/00000009/00000002 / art00002

and Katherine Park observed of the Wunderkammer, 'If each object by itself elicited wonder, all of them densely arrayed floor to ceiling or drawer upon drawer could only amplify the visitor's gasp of mingled astonishment and admiration' (2001: 260). The recently curated mass displays in natural history museums, and indeed Dion's Wunderkammer, strive for a similar effect.

Yet, the reasons that wonder can be a productive response to ecological crisis need to be explored. The curator and art historian Celina Jeffery has noted Oceanomania's 'inherent paradox of using wonder to reinscribe consideration of contemporary threats to the ocean' (2015a: 179). However, wonder takes many different forms and occurs in response to wide-ranging circumstances, making it a rather slippery mode of affect. Although the positive connotations of 'wonder' are commonly known, the Oxford English Dictionary lists among its historical definitions 'an evil or shameful action', 'destruction, disaster' , 'great distress or grief', and 'dreadfully, horribly, terribly' (Rubenstein 2008: 9). The philosopher Mary Jane Rubenstein explored these supressed meanings to reveal how one etymological root of wonder lies in 'Wunde: cut, gash, wound', suggesting that like a wound, 'wonder is only wonder when it remains open [...] to the fantastic and amazing but also to the dreadful and the threatening' (Rubenstein 2008: 9-11, original emphasis). ${ }^{18}$ According to this definition, wonder becomes rather ambiguous, associated at once with dread and delight. By simultaneously marking the celebration and exploitation of ocean life, Oceanomania embraces pleasure and peril in equal measure, rendering the affective force of wonder integral rather than oppositional to a consideration of the current ecological crisis. Given that wonder has been attributed the capacity to lead to the cultivation of an 
(C) Sarah Wade, 2020. The definitive, peer reviewed and edited version of this article is published in Journal of Curatorial Studies, 9.2, 2020, 162-181, DOI: 10.1386/jcs_00019_1 and URL:

https: / / www.ingentaconnect.com/ contentone/intellect/jcs / 2020/00000009/00000002 / art00002

ethical sensibility and to elicit compassion in recent years, ${ }^{19}$ its mobilization via this contemporary cabinet of curiosities becomes somewhat strategic. For the political

theorist Jane Bennett, the affective force of wonder is fundamental to what she refers to as an 'ethical, ecologically aware life', since in moments of wonder one might feel 'connected in an affirmative way to existence', and therefore feel encouraged 'to give away [...] time and effort on behalf of other creatures' $(2001: 99,156)$. Wonder therefore holds out promise in the context of this Museum.

The museum curator Kirsten Wehner argues that curatorial practices harnessing emotional encounters with objects (specifically preserved animal remains) have the potential to create museum spaces that can enhance the empathetic responses of visitors (2017: 88). When advocating for the protection of wildlife and habitats through exhibitions, wonder offers a route towards inciting an ecological sensibility (Endt-Jones 2017: 179). Its affective force can evoke empathy and induce a desire for visitors to care and even act in the face of the threats facing the oceans. Through Dion's installation, the historical collection at the Musée Océanographique de Monaco is mobilized in ecological ways, evoking an ambiguous sense of wonder towards advancing the Museum's aim to promote the protection of oceans and ocean life.

\section{Shark Conservation and Strategic Anthropomorphism}

Exhibitions promoting ocean ecology and marine wildlife conservation present inherent challenges. Obstacles arise because the sea can seem so foreign and uninhabitable from the terrestrial perspective of humans, that marine wildlife can often appear radically other and the depths of the oceans unfathomable. This perceived distance and 
(C) Sarah Wade, 2020. The definitive, peer reviewed and edited version of this article is published in Journal of Curatorial Studies, 9.2, 2020, 162-181, DOI: 10.1386/jcs_00019_1 and URL:

https: / / www.ingentaconnect.com/ contentone/intellect/jcs / 2020/00000009/00000002 / art00002

difference can result in the extension of empathy and compassion being less readily elicited towards far from human forms of life, such as sea creatures, in the face of their plights. Furthermore, it can lead to the welfare of marine wildlife being overlooked and even disregarded (Singer 2010). The challenge of promoting marine wildlife conservation is only compounded when the creature in question has a fearsome reputation, as is the case with sharks. Each year 100 million sharks are killed as a result of being caught as by-catch, tangled in fishing nets or through the controversial practice of shark finning, whereby the fins are cut from live sharks for use in luxury cuisine and often the creatures are then thrown back into the water, where they are no longer able to survive (World Wide Fund for Nature n.d.). As a keystone species, sharks are essential for maintaining the equilibrium of marine ecosystems and the reduction or eradication of sharks from the oceans will have serious environmental effects. Yet, the ferocious reputation of sharks poses a problem when it comes to fostering compassion and inducing ecological action in the face of their plights (Martin 2003: xi). It was in response to the difficulties of promoting shark protection that the Musée Océanographique de Monaco mounted Sharks: A Thrilling Experience and the contemporary art exhibition On Sharks $\mathcal{E}$ Humanity. These exhibitions adopted a curatorial approach that sought to render sharks familiar and less fearsome by combining multisensory displays about shark physiology and behaviour with contemporary artworks, at the same time as harnessing anthropomorphism as a strategic tool to foster empathy and understanding across species lines.

Presented amongst the existing museum displays, these two exhibitions ran concurrently for a year and with no rigid boundaries demarcating them, created various 
(C) Sarah Wade, 2020. The definitive, peer reviewed and edited version of this article is published in Journal of Curatorial Studies, 9.2, 2020, 162-181, DOI: 10.1386/jcs_00019_1 and URL:

https: / / www.ingentaconnect.com/ contentone/intellect/jcs / 2020/00000009/00000002 / art00002

dialogues through the resulting entanglements of nature and culture, humans and nonhumans that arose through the exhibits. Collectively these exhibitions aimed to counter the reputation of sharks as ruthless, vicious killers and instigate a sea-change in longstanding public perceptions of these creatures, from posing a threat to being threatened in order to promote shark protection amongst visitors. While the zoologist Peter Funch has argued that 'Single-species approaches to conservation are not sufficient for an entangled world' (2017: 151), a curatorial focus on a single animal can provide a focussed exhibitionary framework through which to engage visitors in wildlife conservation concerns. The Musée Océanographique de Monaco has often taken this approach, with dedicated programming that has examined sharks, turtles and coral respectively.

Launched on World Oceans Day 2013, Sharks: A Thrilling Experience aimed to educate visitors about shark behaviour and physiology through interactive exhibits that drew attention to various facets of their fascinating lives and bodies. Visitors were offered the opportunity to touch shark's teeth, caress shark skin and even encounter live sharks in a 'petting pool'. The curatorial strategy aimed to render sharks more familiar and as a result less frightening, activating the emotions through a 'fun and sensory' exhibition (Sharks: A Thrilling Experience 2013: 7). On Sharks E Humanity was a contemporary art exhibition featuring work by ten Chinese artists, in recognition of China as the largest consumer of shark fin. The exhibition was a collaboration between the arts organization Parkview Arts Action, the Non-Governmental Organization Wild Aid and the Musée Océanographique de Monaco. It aimed to raise awareness of the need for shark protection, bringing an end to overfishing in general, as well as shark 
(C) Sarah Wade, 2020. The definitive, peer reviewed and edited version of this article is published in Journal of Curatorial Studies, 9.2, 2020, 162-181, DOI: 10.1386/jcs_00019_1 and URL:

https: / / www.ingentaconnect.com/ contentone/intellect/jcs / 2020/00000009/00000002 / art00002

finning and the consumption of shark fin in particular. Given the exhibition's aim, it is notable that the show's curator, Huang Du, identified Joseph Beuys's concept of 'social sculpture' - the power of art to transform society - as an informing concept for the show (On Sharks E Humanity 2014: 4).20 The exhibition sought to bring about social change, shifting perceptions and behaviour towards sharks by encouraging visitors to 'take action through thought, dialogue, discussion and exchange', as a result of encounters with the works on display. ${ }^{21}$ After the stint in Monaco, the exhibition toured to Moscow (2015), Beijing (2015), Singapore (2017), Hong Kong (2017) and Sydney (2018-19) with the intention of taking shark protection issues to an international audience.

(figure 3)

In both of these exhibitions anthropomorphism was used as a curatorial and promotional strategy to induce a generous disposition towards sharks, with various tactics being deployed to collapse the boundaries between humans and sharks towards enabling visitors to relate to these creatures on the basis of recognizing similarity, empathizing with their plights as a result (La Caze 2002: 13). While anthropomorphism contributed to realizing these exhibitions' aims of rendering sharks less fearsome and more familiar, its use could also be criticized for being anthropocentric and for failing to take sharks into account on their own terms. However, anthropomorphism is a complex phenomenon that can be harnessed strategically towards ecological ends if it is carefully and respectfully deployed. Numerous scholars from the 1970s onwards have 
(C) Sarah Wade, 2020. The definitive, peer reviewed and edited version of this article is published in Journal of Curatorial Studies, 9.2, 2020, 162-181, DOI: 10.1386/jcs_00019_1 and URL:

https: / / www.ingentaconnect.com/ contentone/intellect/jcs / 2020/00000009/00000002 / art00002

recognized the value of anthropomorphism when it comes to promoting responsible behaviour towards nonhuman others and it has even been used as a strategy to foster empathy in other shark conservation campaigns..2 For instance, to engage children in shark protection, the Shark Defenders' use Shark Stanley, an anthropomorphic cartoon character who has the sort of cute and childlike appearance that the primatologist and ethologist Frans de Waal argued is 'designed to evoke endearment and protectiveness' (1999: 260). In the context of museums, anthropomorphism can provide a useful curatorial and interpretation tool to engage visitors with wildlife that might otherwise be difficult to understand. As the curator Richard Sabin has observed, 'Anthropomorphism can work to find areas of common ground' (Lowe et al. 2020), making it easier for visitors to relate to creatures whose more-than-human lifeways are hard to grasp. For these reasons anthropomorphism was a productive strategy in the context of these two shark exhibitions.

For instance, a photograph used in the Sharks: A Thrilling Experience marketing material presented a woman stroking a shark in the petting pool. However, the reflection and composition of the image made it look as if the woman's body was merging into the tail end of the aquatic creature so that she appeared as a kind of sharktailed mermaid. By visually blurring the boundaries between the bodies of sharks and humans, the image attempted to make sharks more similar and easier to comprehend from a human perspective. Indeed, it has been observed that for communities living in close proximity to sharks, these creature's have been variously considered as ancestors, Gods and even shapeshifters in stories where humans 'become shark' or sharks 'become human', fostering respect towards these creatures and promoting harmonious 
(C) Sarah Wade, 2020. The definitive, peer reviewed and edited version of this article is published in Journal of Curatorial Studies, 9.2, 2020, 162-181, DOI: 10.1386/jcs_00019_1 and URL:

https: / / www.ingentaconnect.com/ contentone/intellect/jcs / 2020/00000009/00000002 / art00002

interspecies relations as a result (Crawford 2008: 47-58). The promotional photograph transferred the ethical and empathetic possibilities of blurring the boundaries between sharks and humans into the context of the museum to advance a shark protection agenda.

(figure 4)

Anthropomorphism was also in action in On Sharks $\mathcal{E}$ Humanity. One of the largest installations in the show was the site-specific work The Net (2014) by Wang Luyan. It took the form of a giant green fishing net made from steel, which shrouded a room of the museum during the exhibition and surrounded visitors on all sides. The installation was conceived by the artist as an attempt to place the human in the position of a shark caught in a fishing net, in the hope that visitors would consider the experience from the perspectives of sharks and empathize with these creatures as a result (Parkview Arts Action n.d.). As such, the work functioned on the basis of a sense of 'applied anthropomorphism' as conceived by the animal advocate and anti-cruelty campaigner Randall Lockwood, whereby humans use their 'own personal perspective on what it's like to be a living being to suggest ideas about what it is like to be some other being of either our own or some other species' (1989: 49). In this way, the experience of sharks was rendered more accessible to the human imagination and the perceived alterity of these creatures became easier to assimilate and even understand.

Anthropomorphism was used strategically in these two shark exhibitions to foster kinship with sharks. The particular kind of anthropomorphism at work can be 
(C) Sarah Wade, 2020. The definitive, peer reviewed and edited version of this article is published in Journal of Curatorial Studies, 9.2, 2020, 162-181, DOI: 10.1386/jcs_00019_1 and URL:

https: / / www.ingentaconnect.com/ contentone/intellect/jcs / 2020/00000009/00000002 / art00002

described more specifically as what the animal studies scholar Kari Weil has defined elsewhere as critical anthropomorphism, in which recognition of and respect for the ultimate differences of these creatures remained at the very same time they were understood on human terms (Weil 2012: 31). This was achieved through the curatorial move to juxtapose exhibits that readily invited anthropomorphic identification, such as Luyan's installation, with displays that presented these creatures' radically different lifeworlds and fascinating lifeways via specimens such as a shark's jaw, which showed multiple rows of teeth. By simultaneously presenting objects, specimens and artworks that communicated the differences and similarities between sharks and humans, a nuanced mode of critical anthropomorphism surfaced in these exhibitions, which was cognizant of the reductive potential of this way of relating to nonhuman others and therefore remained resistant to diminishing the unique characteristics of these threatened species.

(figure 5)

There was an admirable shark protection agenda at the heart of these exhibitions, yet they nevertheless embodied the ambiguity Morton positioned as being central to being ecological (2018: 108) by giving rise to various contradictions. For instance, the shark petting pool was a particularly ambiguous feature of the displays since while it may have allayed fear of sharks, it did so by keeping these creatures captive. Although the tank-bound sharks undoubtedly did important ambassadorial work for their wild kin, they did so at the cost of being housed in a sterile looking aquarium, which while 
(C) Sarah Wade, 2020. The definitive, peer reviewed and edited version of this article is published in Journal of Curatorial Studies, 9.2, 2020, 162-181, DOI: 10.1386/jcs_00019_1 and URL:

https: / / www.ingentaconnect.com/ contentone/intellect/jcs / 2020/00000009/00000002 / art00002

functionally catering to the immediate needs of these creatures, did not replicate their wider ecosystem in a way that might have provided a richer habitat for these sharks for the duration of the exhibition. The Museum was careful to observe the 'sustainable' origins of these sharks, which were born in captivity rather than taken from the wild, providing an example of the sort of interpretative caveat that often accompanies museum exhibitions featuring live animals (Sharks: A Thrilling Experience 2013: 13). A similar reassurance was provided at Eco-Visionaries (2019-20), a recent exhibition at the Royal Academy of Arts in London, which featured live jellyfish in Rimini Protokoll's installation win><win (2017). On exiting the exhibition, visitors were informed about the measures in place to care for these creatures. Yet, rather than demonstrating that this was a rich environment for the jellies, the text focused instead on routine feeding and cleaning, additionally highlighting that these were common jellyfish found all over the world and that they would probably survive longer in captivity than in the wild. As such, the inherent conflict of putting live animals on display in exhibitions about ecology can undercut a 'green' agenda for some visitors (Rectanus 2020: 143) and the Musée Océanographique de Monaco was therefore also open to this potential risk. In addition, considering the environmental tenet of these shark exhibitions, it is notable that international shows such as On Sharks $\mathcal{E}$ Humanity risk the production of large carbon footprints, especially when they take the form of touring exhibitions, which museums need to manage in sustainable ways.

These exhibitionary ambiguities are further compounded when considered in the context of the Musée Océanographique de Monaco's broader exhibition programme. For instance, when the museum inaugurated its contemporary art programme in 2010, 
(C) Sarah Wade, 2020. The definitive, peer reviewed and edited version of this article is published in Journal of Curatorial Studies, 9.2, 2020, 162-181, DOI: 10.1386/jcs_00019_1 and URL:

https: / / www.ingentaconnect.com/ contentone/intellect/jcs / 2020/00000009/00000002 / art00002

it did so with an exhibition by Damien Hirst that featured two of the artist's large sharks preserved in formaldehyde, which are famously fished to order. The display of such works conflicts with the subsequent shark conservation agenda at the Musée Océanographique de Monaco and also testifies to the difficulty of implementing ecological exhibitions with consistency and without ambiguity across a large institution and its longer history.

\section{'Staying with the Trouble' of Curating Ecology}

These observations should not prohibit or discredit attempts to respond to ecological crisis at this Museum. It is worth emphasizing that the Musée Océanographique de Monaco, along with the associated Oceanographic Institute, regularly carry out international advocacy and lobbying work towards securing more promising futures for marine life. It also takes a sustainable approach to its operational running, testifying to an embedded ecological approach at this Museum that is manifested through campaigning and direct action, as well as exhibitions. Instead, the conflicts and ambiguities arising through these exhibitions demand that curators and museum professionals enact what Donna Haraway recently referred to as 'learning to stay with the trouble of living and dying in response-ability on a damaged earth' (2016: 2) as they strive to respond creatively and ecologically to marine wildlife conservation issues within the infrastructure and history of this museum. For Haraway, learning to stay with the trouble is an on-going commitment to finding better ways of inhabiting the present, as beings entangled with others in manifold ways at a time of ecological distress. It requires positive persistence rather than resignation in the face of ecological 
(C) Sarah Wade, 2020. The definitive, peer reviewed and edited version of this article is published in Journal of Curatorial Studies, 9.2, 2020, 162-181, DOI: 10.1386/jcs_00019_1 and URL:

https: / / www.ingentaconnect.com/ contentone/intellect/jcs / 2020/00000009/00000002 / art00002

crisis (Haraway 2016: 1-4).

For curators at the Musée Océanographique de Monaco, this has involved experimenting with ecological modes of exhibition making, which result in displays that prompt staff and visitors to consider how they are enmeshed with others. This curatorial methodology enacts what Timothy Morton calls ‘The ecological thought', 'a practice and a process of becoming fully aware of how human beings are connected with other beings' (2010: 7). Recognizing connections can have important consequences for the Museum's aim to promote knowing, loving and protecting the oceans, fostering kinship with marine wildlife to result in an ethic of care. Yet, as both Oceanomania and the shark exhibition programme made clear, these interconnections can be negatively as well as positively configured making it necessary for curators to grapple with and attend to ecological ambiguity and stay with the trouble of doing so when developing exhibitions.

Museum curating is complicated. It involves commitment and diplomacy as well as creativity and intellectual rigor as professionals navigate institutional policies and personal politics, work within the confines of fixed budgets and spaces, attend to the needs and preferences of broad audiences at the same time as developing exhibitions that are inclusive, informative, entertaining, thoughtful and that ultimately leave a lasting impression on visitors. At times it can be a balancing act and at others it can result in compromise. Yet, curators have a responsibility to respond in ethical and sustainable ways to the pressing issues of the time in the context of museums and their histories. While there are no straightforward solutions or quick-fix resolutions to the issues facing the oceans and marine wildlife today, these exhibitions provide 
(C) Sarah Wade, 2020. The definitive, peer reviewed and edited version of this article is published in Journal of Curatorial Studies, 9.2, 2020, 162-181, DOI: 10.1386/jcs_00019_1 and URL:

https: / / www.ingentaconnect.com/ contentone/intellect/jcs / 2020/00000009/00000002 / art00002

experimental spaces to think these sort of ecological issues through. They facilitate reflection and discussion about human relationships to nonhumans in all their messy ambiguity to effectively bring nonhumans within the realm of ethical consideration and action.

Figure 1: Musée Océanographique de Monaco, recent exterior view. Photo: Courtesy of S. Péroumal / Institut Océanographique de Monaco.

Figure 2: Mark Dion, Oceanomania (2011), installation view. Photo: Courtesy of M. Dagnino / Institut Océanographique de Monaco/Mark Dion.

Figure 3: Sharks: A Thrilling Experience (2013-15), promotional image of shark petting pool. Photo: Courtesy of T. Ameller / Institut Océanographique de Monaco.

Figure 4: Wang Luyan, The Net (2014), installation view, Musée Océanographique de Monaco. Photo: Courtesy of T. Ameller / Institut Océanographique de Monaco / Parkview Arts Action / Wang Luyan.

Figure 5: Shark petting pool c. 2013, installation view, Musée Océanographique de Monaco. Photo: Courtesy of M. Dagnino / Institut Océanographique de Monaco.

\section{References}

Adler, Anthony (2019), Neptune's Laboratory: Fantasy, Fear, and Science at Sea, Cambridge MA: Harvard University Press.

Alaimo, Stacy (2016), Exposure: Environmental Politics and Pleasure in Posthuman Times, Minneapolis and London: University of Minnesota Press. 
(C) Sarah Wade, 2020. The definitive, peer reviewed and edited version of this article is published in Journal of Curatorial Studies, 9.2, 2020, 162-181, DOI: 10.1386/jcs_00019_1 and URL:

https: / / www.ingentaconnect.com/ contentone/intellect/jcs / 2020/00000009/00000002 / art00002

Arends, Bergit (2019), 'Decolonising Natural History Collections Through

Contemporary Art', in Camilla Rossi-Linnemann and Giulia de Martini (eds), Art in Science Museums: Towards a Post-Disciplinary Approach, Oxon: Routledge, pp. 213-23.

Arnold, Ken (2006), Cabinets for the Curious: Looking Back at Early English Museums, Aldershot: Ashgate.

Basta, Sarina and McAllister, Jackie (2011), 'Exhibition as Expedition, Museum as Object, or Mark Dion's Deep Sea Maneuvering', in Mark Dion (ed.), Oceanomania: Souvenirs of Mysterious Seas: From the Expedition to the Aquarium, London: Mack, pp. 147-69.

Bennett, Jane (2001), The Enchantment of Modern Life: Attachments, Crossings, and Ethics, Princeton: Princeton University Press.

Bine-Muller, Noëlle (2010), Musée Océanographique de Monaco: 1910-2010, Monaco: Éditions La Gazette de Monaco.

Bredekamp, Horst (1995), The Lure of Antiquity and the Cult of the Machine, Princeton: Marcus Wiener.

Calcagno, Robert and Beaud, Marie-Claude (2011a), 'Curious!', in An Illustrated Guide to the Oceanomania Cabinet and Exhibition of Mark Dion at the Oceanographic Museum and Aquarium of Monaco, Monaco: Éditions du Rocher, pp. 3-5.

(2011b), 'Curious!', in Mark Dion (ed.), Oceanomania: Souvenirs of Mysterious

Seas: From the Expedition to the Aquarium, London: Mack, pp. 19-24.

Cameron, Fiona R. (2015), 'Ecologizing Experimentations: A Method and Manifesto for Composing a Post-humanist Museum', in Fiona R. Cameron and Brett Neilson 
(C) Sarah Wade, 2020. The definitive, peer reviewed and edited version of this article is published in Journal of Curatorial Studies, 9.2, 2020, 162-181, DOI: 10.1386/jcs_00019_1 and URL:

https: / / www.ingentaconnect.com/ contentone/intellect/jcs / 2020/00000009/00000002 / art00002

(eds), Climate Change and Museum Futures, New York and London, Routledge, pp. 16-33.

Carpine-Lancre, Jacqueline (2003), ‘Oceanographic Sovereigns: Prince Albert I of Monaco and King Carlos I of Portugal', in Margaret Deacon, Tony Rice and Colin Summerhayes (eds), Understanding the Oceans: A Century of Ocean Exploration, New York and London, Routledge, pp. 56-68.

Carroll La, Khadija (2011), 'Object to Project: Artists' Interventions in Museum Collections', in Christopher R. Marshall (ed.), Sculpture and the Museum, Farnham: Ashgate, pp. 217-39.

Crawford, Dean (2008), Shark, London: Reaktion.

Crutzen, Paul J. and Stoermer, Eugene (2000), 'The Anthropocene', Global Change Newsletter, 41, pp. 17-18.

Daston, Lorraine and Park, Katherine (2001), Wonders and the Order of Nature: 1150-1750, New York: Zone Books.

De Waal, Frans B.M. (1999), 'Anthropomorphism and Anthropodenial: Consistency in Our Thinking about Humans and Other Animals', Philosophical Topics, 27:1, pp. 255-80.

Dion, Mark (ed.) (2011), Oceanomania: Souvenirs of Mysterious Seas, From the Expedition to the Aquarium, London: Mack.

Endt, Marion (2007), ‘Beyond Institutional Critique: Mark Dion's Surrealist Wunderkammer at the Manchester Museum', Museum and Society, 5:1, pp. 1-14. Endt-Jones, Marion (2017), 'Coral Fishing and Pearl Diving: Curatorial Approaches to Doubt and Wonder', in Christian Mieves and Irene Brown (eds), Wonder in 
(C) Sarah Wade, 2020. The definitive, peer reviewed and edited version of this article is published in Journal of Curatorial Studies, 9.2, 2020, 162-181, DOI: 10.1386/jcs_00019_1 and URL:

https: / / www.ingentaconnect.com/ contentone/intellect/jcs / 2020/00000009/00000002 / art00002

Contemporary Artistic Practice, London and New York: Routledge, pp. 177-93.

Findlen, Paula (1994), Possessing Nature, Los Angeles: University of Los Angeles Press.

Fudge, Erica (2002), Animal, London: Reaktion.

Funch, Peter (2017), ‘Synchronies at Risk: The Intertwined Lives of Horseshoe

Crabs and Red Knot Birds', in Anna Tsing, Heather Swanson, Elaine Gan and

Nils Bubandt (eds), Arts of Living on a Damaged Planet: Monsters, Minneapolis and

London: University of Minnesota Press, pp. 143-54.

Green, Alison (2018), When Artists Curate: Contemporary Art and the Exhibition as Medium, London: Reaktion Books.

Haraway, Donna (1984), 'Teddy Bear Patriarchy: Taxidermy in the Garden of Eden, New York City 1908-1936', Social Text, 11, pp. 20-64. (2016), Staying with the Trouble: Making Kin in the Chthulucene, Durham and London: Duke University Press.

Harlan, Volker (2004), What is Art? Conversation with Joseph Beuys, trans. by Matthew Barton and Shelley Sacks, Forest Row: Clairview Books.

Hepburn, Ronald (1984), 'Wonder' and Other Essays, Edinburgh: Edinburgh University Press, pp. 131-54.

Hoare, Philip (2014), ‘Museum and Gallery Curators Reopen the Cabinet of Curiosities Concept', Guardian, 13 January, https: / / www.theguardian.com/artanddesign/2014/jan/13 / cabinet-curiositiestaxidermy-retro-museums. Accessed 8 December 2019.

H.S.H. The Prince of Monaco (1921), 'Studies of the Ocean', The Scientific Monthly, 13:2, pp. 171-85. 
(C) Sarah Wade, 2020. The definitive, peer reviewed and edited version of this article is published in Journal of Curatorial Studies, 9.2, 2020, 162-181, DOI: 10.1386/jcs_00019_1 and URL:

https: / / www.ingentaconnect.com/ contentone/intellect/jcs / 2020/00000009/00000002 / art00002

Impey, Oliver and MacGregor, Arthur (eds) (1985), The Origins of Museums: The Cabinet of Curiosity in Sixteenth and Seventeenth Century Europe, Oxford: Clarendon.

Institut Océanographique (2019), Institut Océanographique, Fondation Albert 1 ${ }^{\text {, }}$, Prince de Monaco. https: / / www.oceano.org/wpcontent/uploads/2019/06/institut_oceanographique_BD_01.pdf. Accessed 16 July 2020.

Irigaray, Luce (1993), 'Wonder: A Reading of Descartes, The Passions of the Soul', An Ethics of Sexual Difference, trans. Carolyn Burke and Gillian C. Gill, London: Athlone Press, pp. 72-82.

Jeffery, Celina (2015a), 'Artists Curating the Expedition', in Celina Jeffery (ed.), The Artist as Curator, Bristol: Intellect Ltd., pp. 173-88. (ed.) (2015b), The Artist as Curator, Bristol: Intellect Ltd.

Kenseth, Joy (ed.) (1991), The Age of the Marvelous, Hanover: Hood Museum of Art.

La Caze, Marguerite (2002), 'The Encounter Between Wonder and Generosity', Hypatia, 17:3, pp. 1-19. (2013), Wonder E Generosity: Their Role in Ethics and Politics, New York: State University of New York Press.

Lange-Berndt, Petra and Rübel, Dietmar (eds) (2015), Mark Dion: The Academy of Things, Berlin: Walther König.

Lockwood, Randall (1989), 'Anthropomorphism Is Not a Four-letter Word', in R.J. Hoage (ed.), Perceptions of Animals in American Culture, Washington and London: Smithsonian Institution Press, pp. 41-56. 
(C) Sarah Wade, 2020. The definitive, peer reviewed and edited version of this article is published in Journal of Curatorial Studies, 9.2, 2020, 162-181, DOI: 10.1386/jcs_00019_1 and URL:

https: / / www.ingentaconnect.com/ contentone/intellect/jcs / 2020/00000009/00000002 / art00002

Lowe, Miranda, Sabin, Richard, Syperek, Pandora and Wade, Sarah (2020), 'Curating Ocean Ecology at the Natural History Museum: Miranda Lowe and Richard Sabin in Conversation with Pandora Syperek and Sarah Wade', Science Museum Group Journal, 13. http: / /journal.sciencemuseum.ac.uk/browse/issue-

13/ curating-ocean-ecology-at-the-natural-history-museum/. Accessed 17 July 2020. Macgregor, Arthur (2007), Curiosity E Enlightenment: Collectors and Collections from the Sixteenth to the Nineteenth Century, London: Yale University Press.

Martin, Rick (2003), 'Foreword', in Ralph S. Collier, Shark Attacks of the Twentieth Century, Chatsworth: Scientia Publishing, pp. x-xi.

Midgley, Mary (1979), Beast and Man: The Roots of Human Nature, Hassocks: Harvester Press.

Mills, Eric L. and Carpine-Lancre, Jacqueline (1992), 'The Oceanographic Museum of Monaco', in Elisabeth Mann Borgese (ed.), Ocean Frontiers: Explorations by Oceanographers on Five Continents, New York: Harry N. Abrams, pp. 121-35.

Morton, Timothy (2010), The Ecological Thought, Cambridge, MA and London: Harvard University Press. (2018), Being Ecological, London: Pelican.

Mousse Magazine (2011), 'Mark Dion OCEANOMANIA at the Oceanographic Museum and Villa Paloma, Monaco', http: / / moussemagazine.it/mark-dionoceanomania-at-at-the-oceanographic-museum-and-villa-paloma-monaco/. Accessed 8 December 2019.

Oceanographical Museum and Aquarium of Monaco (1935), Illustrated Guide, Monaco. 
(C) Sarah Wade, 2020. The definitive, peer reviewed and edited version of this article is published in Journal of Curatorial Studies, 9.2, 2020, 162-181, DOI: 10.1386/jcs_00019_1 and URL:

https: / / www.ingentaconnect.com/ contentone/intellect/jcs / 2020/00000009/00000002 / art00002

Oceanographic Museum of Monaco (2011), 'History of the Oceanographic Museum, Temple of the Sea', in An Illustrated Guide to the Oceanomania Cabinet and Exhibition of Mark Dion at the Oceanographic Museum and Aquarium of Monaco, Monaco: Éditions du Rocher, pp. 7-11.

On Sharks E Humanity (2014), press kit, Monaco: Oceanographic Museum of Monaco. Parkview Arts Action (n.d.), 'Wang Luyan', http: / / www.parkviewartsaction.com/project/wang-luyan/. Accessed 29 December 2019.

Parsons, Howard L. (1969), 'A Philosophy of Wonder', Philosophical and Phenomenological Research, 30:1, pp. 84-101.

Pomian, Krzysztof (1987), Collectors E Curiosities: Paris and Venice: 1500-1800, Cambridge: Polity Press.

Putnam, James (2009), Art and Artifact: The Museum as Medium, London: Thames and Hudson.

Rectanus, Mark W. (2020), Museums Inside Out: Artist Collaborations and New Exhibition Ecologies, Minneapolis and London: University of Minnesota Press.

Robin, Libby (2018), 'Anthropocene Cabinets of Curiosity: Objects of Strange Change', in Gregg Mitman, Marco Armiero and Robert S. Emmett (eds), Future Remains: A Cabinet of Curiosities for the Anthropocene, Chicago and London: University of Chicago Press, pp. 205-18.

Robins, Claire (2013), Curious Lessons in the Museum: The Pedagogic Potential of Artists' Interventions, New York and London: Routledge. 
(C) Sarah Wade, 2020. The definitive, peer reviewed and edited version of this article is published in Journal of Curatorial Studies, 9.2, 2020, 162-181, DOI: 10.1386/jcs_00019_1 and URL:

https: / / www.ingentaconnect.com/ contentone/intellect/jcs / 2020/00000009/00000002 $/ \operatorname{art00002}$

Rose, Deborah Bird, Van Dooren, Thom and Chrulew, Matthew (eds) (2017), Extinction Studies: Stories of Time, Death, and Generations, New York and Chichester: Columbia University Press.

Rossi-Linnemann, Camilla and de Martini, Giulia (2019), 'Introduction', in Camilla Rossi-Linnemann and Giulia de Martini (eds), Art in Science Museums: Towards a Post-disciplinary Approach, New York and London: Routledge, pp. 7-24.

Rubenstein, Mary Jane (2008), Strange Wonder: The Closure of Metaphysics and the Opening of Awe, New York: Columbia University Press.

Sharks: A Thrilling Experience (2013), press kit, Monaco: Oceanographic Museum of Monaco.

Singer, Peter (2010), 'Fish: The Forgotten Victims on Our Plate', Guardian, 14 September, http: / / www.theguardian.com/ commentisfree/ cif-green/2010/sep/14/fishforgotten-victims. Accessed 8 December 2019.

Stafford, Barbara Maria (2001), Devices of Wonder: From the World in a Box to Images on a Screen, Los Angeles: Getty Institute.

Syperek, Pandora and Wade, Sarah (2020), 'Curating the Sea - Guest Editors' Introduction', Journal of Curatorial Studies, 10.2 (this issue).

Vasalou, Sophia (2015), Wonder: A Grammar, Albany: State University of New York Press.

Wehner, Kirsten (2017), 'Towards an Ecological Museology: Responding to the AnimalObjects of the Australian Institute of Anatomy Collection', in Jennifer Newell, Libby Robin and Kirsten Wehner (eds), Curating the Future: Museums, Communities and Climate Change, London and New York, Routledge, pp. 85-100. 
(C) Sarah Wade, 2020. The definitive, peer reviewed and edited version of this article is published in Journal of Curatorial Studies, 9.2, 2020, 162-181, DOI: 10.1386/jcs_00019_1 and URL:

https: / / www.ingentaconnect.com/ contentone/intellect/jcs / 2020/00000009/00000002 / art00002

Weil, Kari (2012), Thinking Animals: Why Animal Studies Now, New York: Columbia University Press.

World Wide Fund for Nature (n.d.), 'Say \#NoSharkFin', https: / / www.wwf.sg/get_involved/say_no_shark_fin/. Accessed 30 December 2019.

\section{Contributor Details}

Sarah Wade is Lecturer in Museum Studies at University of East Anglia. Her research examines human-animal relations and representations of wildlife in contemporary art and exhibitions, particularly with regards to ecological concerns. She has published on extinction and ecology in contemporary art and curatorial practice. Wade was a cocurator of Strange Creatures: The Art of Unknown Animals at the Grant Museum of Zoology (2015) and has also worked with various arts and heritage organizations.

${ }^{1}$ Prior to the Museum opening, the collections amassed by Prince Albert I were displayed in the Monaco Pavilion at the universal exhibitions in Paris in 1889 and 1900 (Adler 2019: 64; Carpine-Lancre 2003: 62; Mills and Carpine-Lancre 1992: 124). 2See Arends (2019), Carroll La (2011), Robins (2013) and Putnam (2009).

${ }^{3}$ Examples include Science Museum Arts Projects (1999-2014) a programme at the Science Museum, London and the Natural History Museum's contemporary art programme (2005-13). 
(C) Sarah Wade, 2020. The definitive, peer reviewed and edited version of this article is published in Journal of Curatorial Studies, 9.2, 2020, 162-181, DOI: 10.1386/jcs_00019_1 and URL:

https: / / www.ingentaconnect.com/ contentone/intellect/jcs / 2020/00000009/00000002 / art00002

${ }^{4}$ Some recent examples of this surge in oceanic exhibitions are detailed in the introduction to this special issue of the Journal of Curatorial Studies on Curating the Sea, see Syperek and Wade (2020).

${ }^{5}$ For example, it was in 1909 that the Victoria and Albert Museum and the Science Museum were reorganized into independent entities, separating the art collections and the science and engineering collections of what was once the South Kensington Museum.

‘See Adler (2019: 65), Bine-Muller (2010: 23), Mills and Carpine-Lancre (1992: 124) and Oceanographical Museum and Aquarium (1935: 3).

- These categories included Littoral, Coastal, Abyssal, Bathypelagic and Pelagic fauna (Oceanographical Museum and Aquarium 1935: 6).

${ }^{8}$ For more on the full extent of Dion's project see Dion (2011) and Jeffery (2015a). For more on the possibilities and histories of the artist as curator see Jeffery (2015b), Green (2018) and Putnam (2009).

9 The museum forms part of the wider Oceanographic Institute, which was founded by Prince Albert I in 1906 to advance the discipline of oceanography and today mediates between scientific and socio-economic bodies, policy makers and the public towards the realization of its mission of knowing, loving and protecting the oceans (Institut Océanographique 2019: 14).

${ }^{10}$ These manufactured hybrids were commonly found in the early modern Wunderkammer. 
(C) Sarah Wade, 2020. The definitive, peer reviewed and edited version of this article is published in Journal of Curatorial Studies, 9.2, 2020, 162-181, DOI: 10.1386/jcs_00019_1 and URL:

https: / / www.ingentaconnect.com/ contentone/intellect/jcs / 2020/00000009/00000002 / art00002

"See Basta and McAllister (2011: 149), Dion (2011: 174-75), Jeffery (2015a: 175) and Mousse Magazine (2011).

${ }_{12}$ See Bredekamp (1995), Daston and Park (2001), Findlen (1994) and Kenseth (1991).

${ }_{13}^{13}$ See e.g. Arnold (2006), Bredekamp (1995), Daston and Park (2001), Findlen (1994), Impey and MacGregor (1985), Kenseth (1991), MacGregor (2007) and Pomian (1987).

The Victoria and Albert Museum, London, also started a two-part research project 'Opening the Cabinet of Curiosities' in 2017.

${ }_{14}^{14}$ See e.g. Endt (2007).

${ }^{15}$ The Sixth Mass Extinction is a moment of elevated species loss, which differs from the five extinction events preceding it since it is principally brought about by anthropogenic activity (Rose, Van Dooren and Chrulew 2017: 1).

${ }^{16}$ For example, there was a cabinet of curiosities included in the exhibition Welcome to the Anthropocene: The Earth in Our Hands (2014) at the Deutsches Museum, Munich.

${ }^{17}$ On the proposed designation of the Anthropocene, see Crutzen and Stoermer (2000).

${ }^{18}$ Rubenstein cites the philosopher Howard L. Parsons (1969: 85).

${ }_{19}$ See Bennett (2001), Hepburn (1984), Irigaray (1993), La Caze (2002, 2013) and Vasalou (2015).

${ }^{20}$ For Beuys, social sculpture referred to the way 'we mould and shape the world in which we live', and that to realize its capacity to transform society, everyone must be an artist (cited in Harlan 2004: 9).

${ }^{21}$ From exhibition interpretation text at the Musée Océanographique de Monaco. ${ }_{22}$ See Midgley (1979: 349), de Waal (1999: 264), Fudge (2000: 76) and Weil (2012). 